\title{
SUBTERRANEAN SILOS AT VRÁBLE, SOUTHWESTERN SLOVAKIA
}

\section{A Case Study of Geochemistry and Distribution of Finds in Fill Deposits}

\author{
M A R I I VANOVA - FRANK SCHLÜTZ - NORBERT B E NECKE
}

\begin{abstract}
The purpose of this study is to assess the potential of detailed sampling and the correlation of proxies to explain the origin and formation of secondary deposits in subterranean storage facilities. For that we studied the stratigraphy, soil chemistry and the distribution of artifacts, animal bones and microscopic remains in the backfills of two bell-shaped storage pits from the Early Bronze Age (ca. 2000-1600 BC) site Fidvár near Vráble in southwestern Slovakia. The data indicate a number of correlations between the archaeological, biological and geochemical proxies. The soil chemistry and the microscopic remains indicate a complex history of formation. Phosphorus content varies throughout the pit and correlates with the distribution of plant remains, showing differences in the origin of deposits in the separate parts of the features. Mineralized Chenopodiaceae and burned plant material, in particular, correlate with high phosphorus content, probably due to the presence of animal dung in parts of the pit fills. In contrast, there is no clear correlation between the distribution of archaeological finds and other proxies, suggesting that the exclusive reliance on artifacts as indicators for the origin of pit deposits might be problematic. The study demonstrates that the integration of proxies can provide better insights into the taphonomic history of subterranean features and can be related to particular human activities in their vicinity. For regions and periods where pits are the major or only archaeological feature at prehistoric sites, such detailed analyses can provide valuable insights into the economic, social and ritual practices of former societies.
\end{abstract}

Keywords: Slovakia, Early Bronze Age, subterranean silos, pit deposits, taphonomy, pXRF, soil chemistry, artifact distributions, archaeobotany, archaeozoology.

\section{INTRODUCTION}

The wide range of possible motivations for the digging of pits has often puzzled archaeologists and made it difficult to identify the intent and function of pits in prehistoric contexts. A notable exception are the peculiar pits with bell-shaped sections, whose use as grain silos is well-documented in ancient written sources as well as in the ethnographic record. Until recently, almost identical storage installations were regularly used by a variety of societies in Africa, South America, Europe, the Eastern Mediterranean and the Middle East (Currid/Navon 1989; Fairbairn/Omura 2005; Fenton 1983; Füzes 1981; Gronenborn 1997; Kadim 2014; Makal 1954; Mruškovič 1962; Nicolaisen 1963; Peters 1979; Reynolds 1974; Robinson 1963). Bell-shaped pits are ubiquitous at prehistoric sites across Europe and, given the plentiful ethnographic evidence, they have been widely recognized as grain storage facilities. Previous research has dealt with the typology and dating of the finds from the backfill, while work on the nature of the deposits themselves is rare (Balbo et al. 2015; Ernée 2005; 2008; Kadrow 1992; Kuna/Němcová 2012; Toffolo et al. 2018). However, as demonstrated by studies of M. L. Shackley (1976) and J. D. Hill (1995), combined analysis of sedimentation patterns and the verti- cal distribution of finds in the backfill can greatly advance our understanding of pit use.

In this paper, we assess the potential of systematic sampling of backfills for reconstructing the modes of original and secondary uses of storage pits. We analyzed the sediment stratigraphy, archaeological finds, animal bones and microscopical remains and the geochemical composition of two bell-shaped pits from the Early Bronze Age site at Vráble (Southwestern Slovakia) to question their original purpose and especially the sequence of processes that followed after the stored contents were removed. The results demonstrate that observations on the nature and origin of fill deposits can help to understand the cycles of use, and the abandonment and re-use of features in pit clusters and give clues to activities in the surrounding area. We conclude by discussing the value of our analytical strategy for improving the interpretation of subterranean settlement features.

\section{BACKGROUND}

The prehistoric site of Vráble is located above the former bed of the river Žitava near the modern town of Vráble, c. $80 \mathrm{~km}$ to the east of the Slovakian capital Bratislava (Fig. 1). The site belongs to a group 


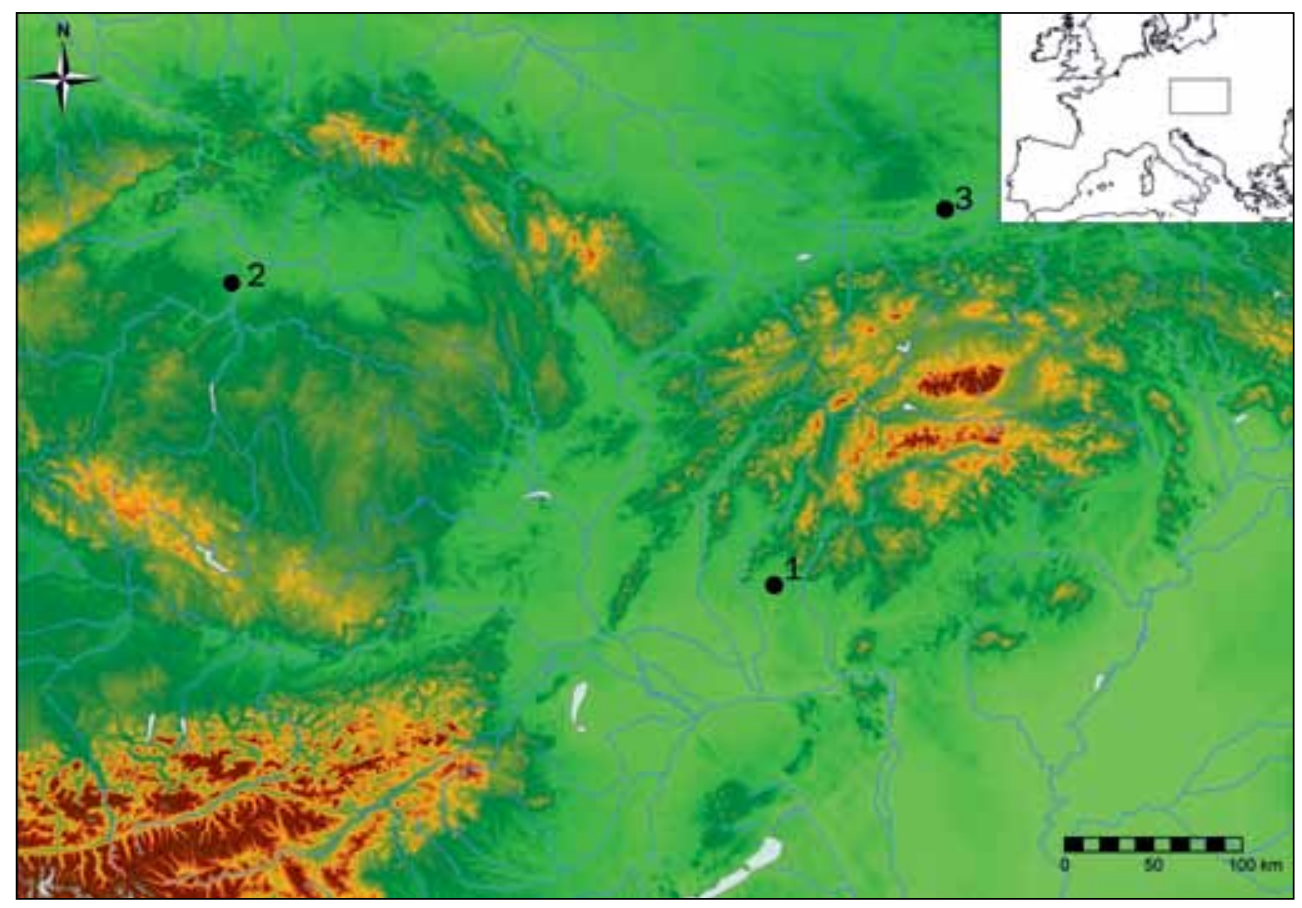

Fig. 1. Map showing the location of Vráble and sites mentioned in the text. 1 - Vráble; 2 - Praha 10 - Záběhlice; 3 - Iwanowice-Babia Góra (author M. Ivanova).

of fortified Early Bronze Age 'tell' settlements in the Carpathian Basin (Gogâltan 2008; Točík 1982). Since 2007, a joint team from the Slovak Institute of Archaeology at Nitra and the Romano-German Commission at Frankfurt has been conducting systematic reconnaissance and excavations (Fig. 2; Bátora et al. 2009; 2012). Large-scale geophysical prospection, trial excavations and broad horizontal exposures have uncovered here the layout of an Early Bronze Age settlement with three enclosing ditches, numerous house remains, alleys, pits, and a cemetery.

The site had three main occupation periods, dating to ca. 2500-2300 BC (Vráble I) and ca. 20001600 BC (Vráble II and III; Bátora et al. 2012). In all three periods bell-shaped pits were dug through the habitation layers into the loess substratum. By 2013 eleven bell-shaped pits had been examined by different research teams. Since most of these features were recovered in small test trenches, their exact relation to the surrounding habitation area remains obscure. An exception are two pits (Pit 101-29 and Pit 101-42) explored in the large exposure 'Area 1' in 2012, which have clear stratigraphic relations to the excavated habitation layers and structures.

Pit 101-29 cuts the northeastern part of a house in Area 1, Trench 101. The funnel-shaped upper part of the pit and a portion of its body were visible in the southern section of the trench, while its narrow neck was not caught by the section (Fig. 3). The opening of the pit had a diameter of ca. $1 \mathrm{~m}$. The pit narrowed to $0.7 \mathrm{~m}$ at a depth of $0.6 \mathrm{~m}$ and then widened to a cone with a base diameter of ca. $2.1 \mathrm{~m}$. The whole feature measured $1.5 \mathrm{~m}$ in depth with a volume of ca. $1.6 \mathrm{~m}^{3}$. Pit 101-29 was found in a remarkably good state of preservation. There were no significant traces of erosion on the carefully cut and smoothed walls of this facility (Fig. 4: 2). Two joining sherds with incrusted decoration from a depth of $30-45 \mathrm{~cm}$ might date to the Madarovce period.

Pit 101-42 disturbed the northwestern part of the same house and was bisected by the southern section of the Trench 101 (Fig. 3). The opening of the pit measured ca. $1.5 \mathrm{~m}$ in diameter. It narrowed to $1 \mathrm{~m}$ at a depth of $0.4 \mathrm{~m}$ and then widened to a bell-shaped body cut into the loess. The diameter at the base measured ca. $2.6 \mathrm{~m}$. Pit 101-42 was ca. $1.9 \mathrm{~m}$ deep with a volume of ca. $4 \mathrm{~m}^{3}$. There were traces of erosion of the walls and the state of preservation of this facility was poorer compared to Pit 101-29 (Fig. 4). Two nearly complete jugs from $45-60 \mathrm{~cm}$ and $75-90 \mathrm{~cm}$ depth date to the Madarovce period.

\section{MATERIALS AND METHODS}

\section{Fieldwork and sampling strategy}

Both pits were exposed and documented by single unit recording. Thicker deposits were removed in $15 \mathrm{~cm}$ spits, with bulk of pottery, animal 


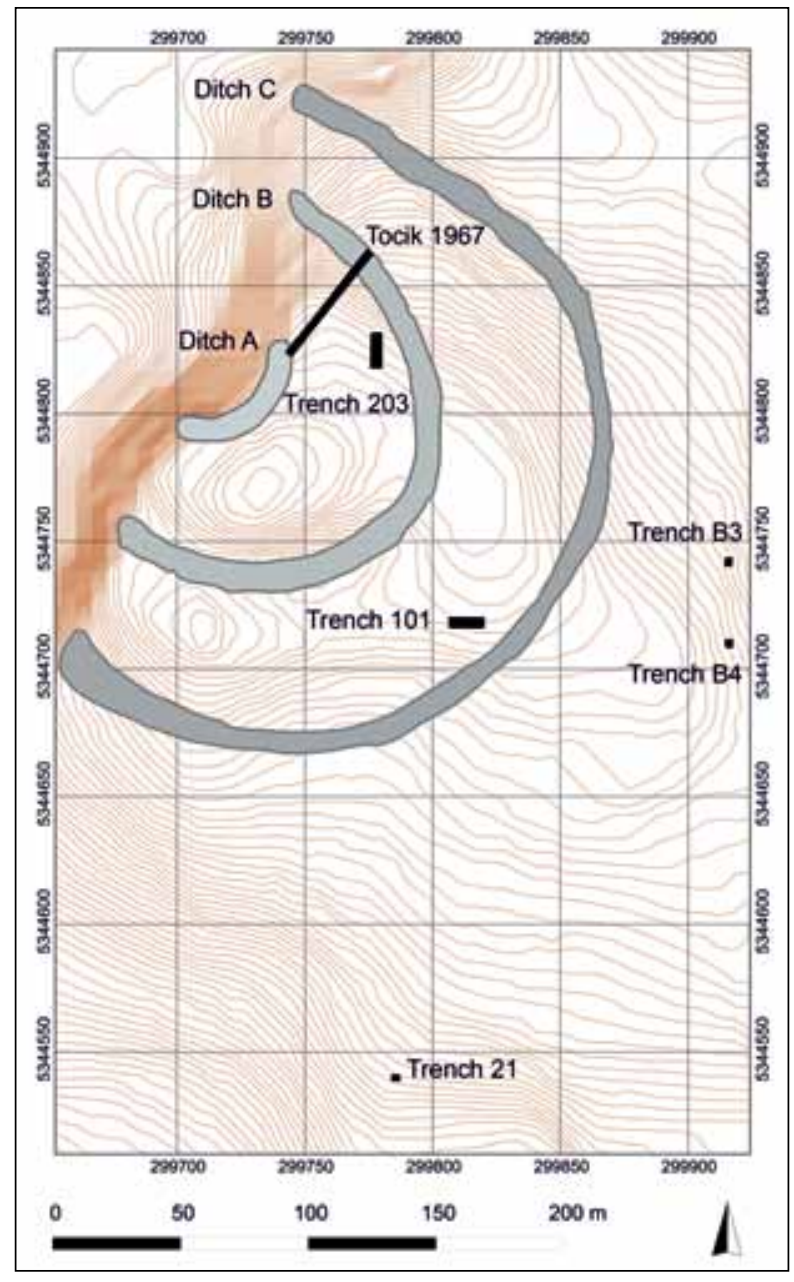

Fig. 2. Plan of the Early Bronze Age site at Vráble and location of trenches with bell-shaped pits (coordinate system: WSG 1984 UTM zone $34 \mathrm{~N}$ ). Ditches drawn according to the magnetic image (author M. Ivanova).

bones, soil samples and flotation samples from each spit recorded separately. Small finds and ceramic vessels were measured in during excavation. Following hand collection the fill sediment was dry sieved with a $10 \mathrm{~mm}$ mesh to recover smaller finds missed during excavation. Separate samples for flotation and analysis of soil chemistry were collected from all stratigraphic units.

\section{Analysis of archaeological finds}

A total of $17.3 \mathrm{~kg}$ pottery, $1.7 \mathrm{~kg}$ fired daub fragments and $1.8 \mathrm{~kg}$ animal bones and clamshells were recovered from Pit 101-29. The excavated deposits of Pit 101-42 incorporated $10.1 \mathrm{~kg}$ pottery, $0.7 \mathrm{~kg}$ fired daub fragments and ca. $1 \mathrm{~kg}$ animal bones and clamshells. In terms of finds assemblages, weight per cubic meter and mean sherd weight (MSW) were calculated for comparisons between the pits. For the study of the vertical distributions, a division into thirds was preferred to a detailed stratigraphic partitioning. This fast and simple approach provided sound results in Hill's meticulous study of Iron Age pits. Upon examination, Hill observed that the tripartite pit division allowed for the detection of vertical patterns without seriously effecting the results (Hill 1995, 45, 52, 53).

\section{Microscopical analysis}

Fifteen samples with volumes from 1.3 to 4.91 were floated in the field into three fractions (3.15/0.71/0.25 mm). The sediment was suspended on a sieve and scoured out by a water jet from below. Two vessel fills were wet sieved in the laboratory. The data of the one vessel fill sample 501 (100 ml) were merged with flotation sample 450 . Remains of the second vessel fill sample $440(150 \mathrm{ml})$ consisted mostly of charcoal. In total, a volume of 461 was processed. The coarse and middle fraction was fully examined under a magnification of 10 to 63, from the fine fraction at least the eight-part was analyzed. The investigation focused on botanical and zoological remains including charred cereal remains, charred and mineralized seeds, charcoal, snail shells, arthropod and vertebrate rests, but also inorganic components were taken into account. Altogether, about 110 types of remains were determined and counted per sample. Charcoal pieces were in addition weighed.

Botanical data were stored and pre-processed with the data base ArchBot (Kreuz/Schäfer 2002), charcoals and snails handled with common calculation software. Concentrations were calculated under consideration of sample volume and in case of botanical remain types of the fine fraction portion. Samples from the same strata were allied (450/501, 459/460). Botanical remains and charcoals have been determined using the type collections of the NIhK (Niedersächsisches Institut für historische Küstenforschung) and literature (Berggren 1981; Bojňanskýl Fargašová 2007; Jacomet 2006). Charcoal proportions are expressed as percentages of the total charcoal weight of each sample. Identification and interpretation of the mollusks are based on P. Davies (2008), J. G. Evans (1972), M. P. Kerney et al. (1983), and F. W. Welter-Schultes (2012). Their concentrations are given in $\mathrm{n} / \mathrm{l}$ with $\mathrm{n}$ representing the minimum number of individuals (Carrott/Kenward/Milles 1996). Percentages of shells refer to the total number of shells per sample. The phosphatized status of remains was identified chemically (Gundlach 1961). A selection of all groups of remains is plotted against the middle 


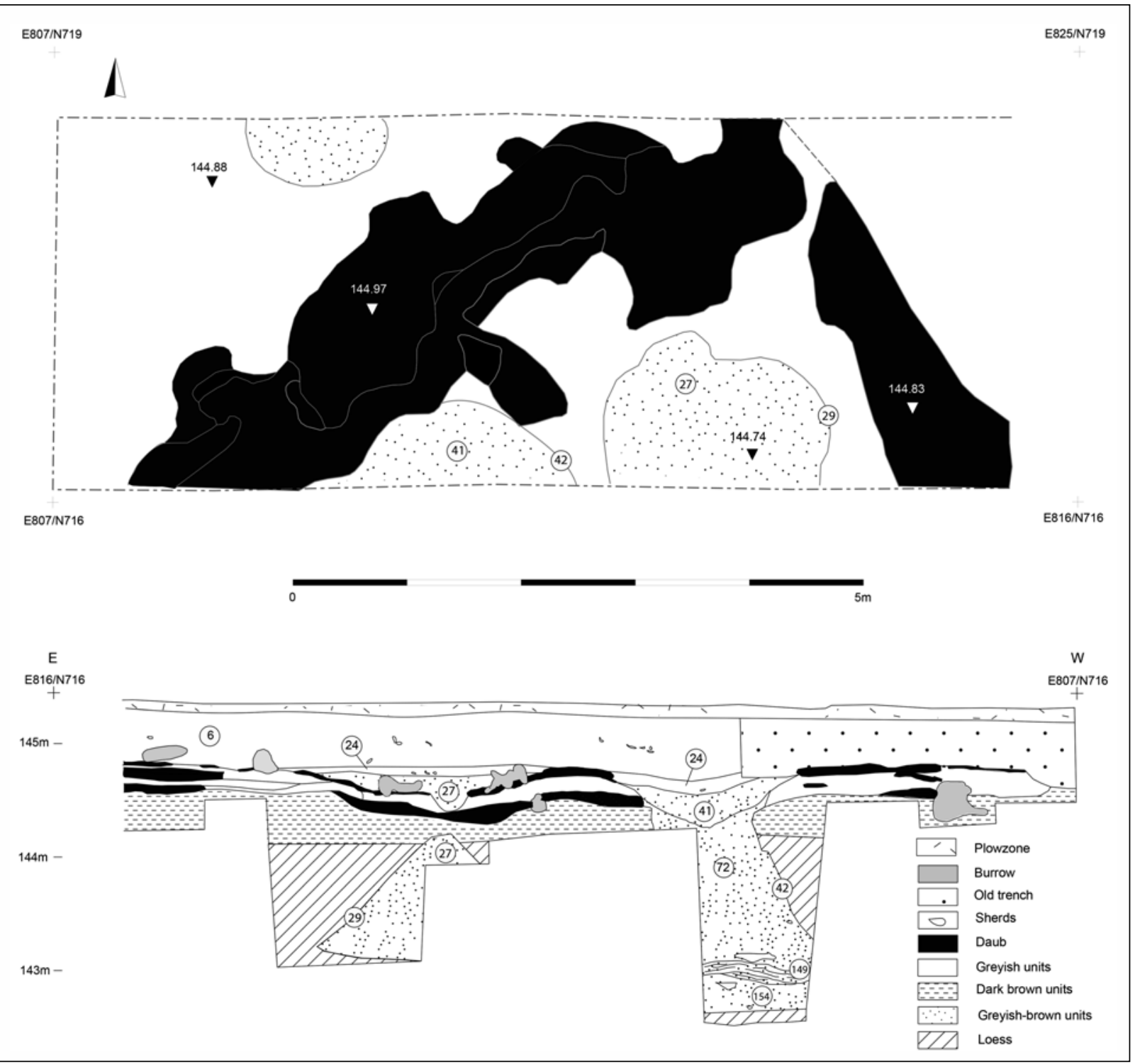

Fig. 3. Plan and south section of Trench 101 at Vráble (author M. Ivanova).

sample depths below the pit tops with the latest software version of C2 (Juggins 2007). The archaeological division of the pits into thirds is marked (Fig. 5).

\section{Sediment analyses using XRF}

A total of 23 sediment samples, ten from Pit 101-29 and thirteen samples from the deeper Pit 101-42, were analyzed. The samples were dried at $105{ }^{\circ} \mathrm{C}$ and compacted into tablets by a hand press (diameter of $11 \mathrm{~mm}$ ). The chemical composition of the samples was determined by $\mathrm{X}$-ray fluorescence (XRF) using a handheld device (Thermo Scientific Niton XL3t XRF Analyzer), fixed in a measurement chamber. The measurement routine, set up by Gauss et al., ran four excitation conditions with an overall measurement time of $150 \mathrm{~s}$ : (1) main filter, $30 \mathrm{~s}$; (2) low filter, $30 \mathrm{~s}$; (3) high filter, $30 \mathrm{~s}$; and (4) light filter, $60 \mathrm{~s}$ (Gauss et al. 2013). To ensure reliability, a sample of the NIST standard 2711 (Montana soil) was measured at the start and end of every measurement series. The internal device error of the PXRF analyser was determined to be $6 \%$ in the case of phosphorus. The P values determined by pXRF were higher by $39 \%$ in comparison to the NIST standard (see Nowaczinski et al. 2013).

The use of XRF data, and in particular the need of good calibration of the portable XRF devices used in the field, has provoked controversies in geoarchaeology (cf. Frahm 2013; Frahm/Doonan 2013; Speakman/ Shackley 2013). Methodological issues of analyzing 

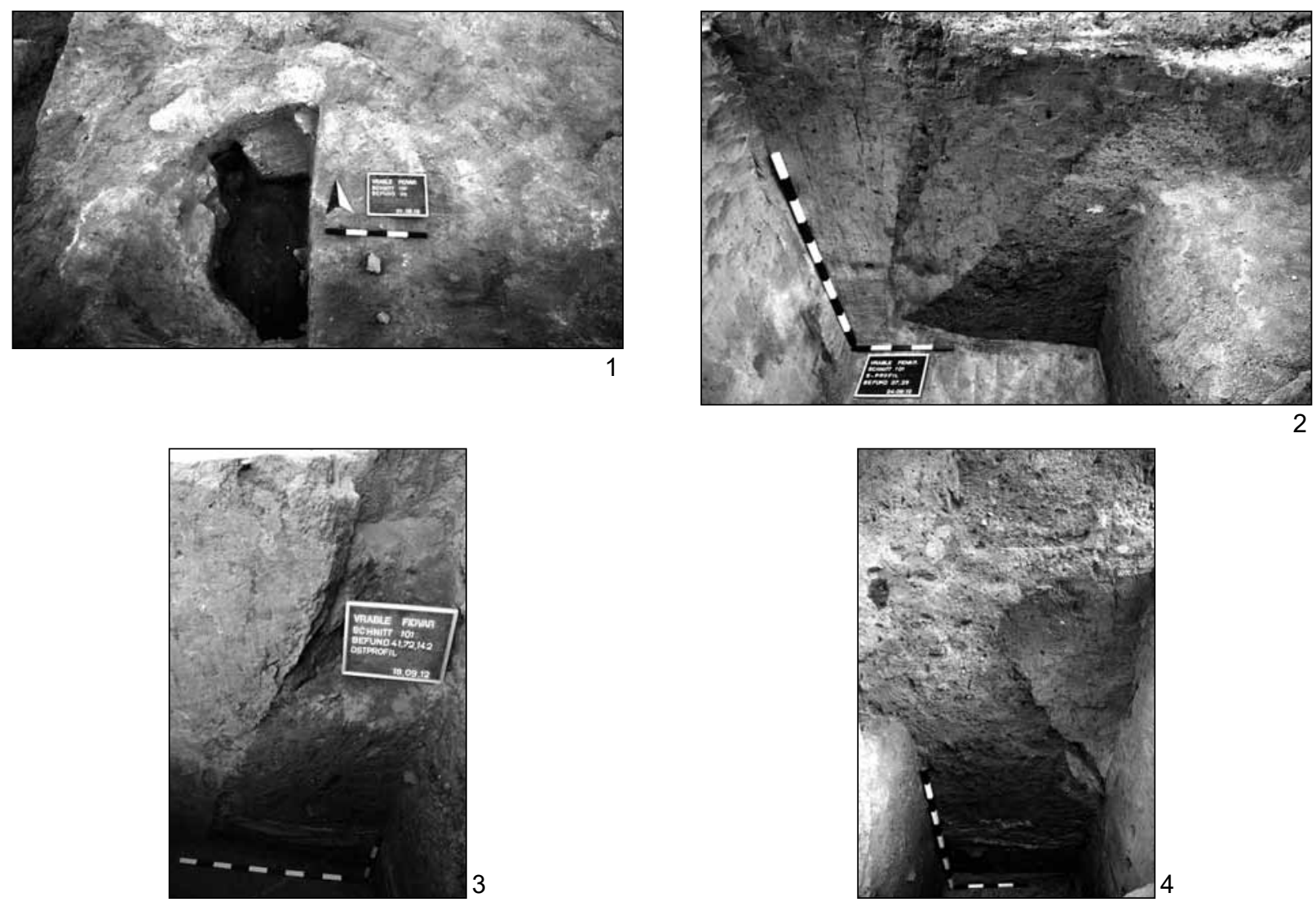

Fig. 4. Vráble. 1 - opening of Pit 101-29; 2 - south section of Pit 101-29; 3 - east section of Pit 101-42; 4 - south section of Pit 101-42 (photos courtesy of the German Archaeological Institute).

Table 1. Vráble. Distribution of finds in the backfill layers of Pit 101-29 and Pit 101-42 and comparison with the midden layer Deposit 101-3/6.

\begin{tabular}{|c|c|c|c|c|c|c|c|c|}
\hline \multirow[b]{2}{*}{ Feature } & \multirow[b]{2}{*}{ Volume* } & \multicolumn{3}{|c|}{ Pottery } & \multirow[b]{2}{*}{ Bones (g) } & \multirow[b]{2}{*}{ Shells (g) } & \multirow[b]{2}{*}{ Daub (g) } & \multirow{2}{*}{$\begin{array}{c}\text { Small finds } \\
\text { (count) }\end{array}$} \\
\hline & & Weight (g) & MSW $+(g)$ & Density $\left(\mathbf{k g} / \mathbf{m}^{3}\right)$ & & & & \\
\hline \multirow[t]{3}{*}{ Pit 101-29 } & $\begin{array}{l}\text { Upper third } \\
0.8 \mathrm{~m}^{3}\end{array}$ & 13874 & 11 & 17 & 1124 & 221 & 1521 & 4 \\
\hline & $\begin{array}{c}\text { Middle third } \\
0.3 \mathrm{~m}^{3}\end{array}$ & 1207 & 10 & 4 & 34 & 39 & 43 & 4 \\
\hline & $\begin{array}{l}\text { Lower third } \\
0.5 \mathrm{~m}^{3}\end{array}$ & 2230 & 9 & 4.5 & 280 & 88 & 79 & 3 \\
\hline \multirow[t]{3}{*}{ Pit 101-42 } & $\begin{array}{l}\text { Upper third } \\
0.3 \mathrm{~m}^{3}\end{array}$ & 2068 & 12 & 7 & 189 & 70 & 64 & 1 \\
\hline & $\begin{array}{c}\text { Middle third } \\
0.3 \mathrm{~m}^{3}\end{array}$ & 7522 & 12 & 21.5 & 731 & 84 & 591 & 2 \\
\hline & $\begin{array}{c}\text { Lower third } \\
0.6 \mathrm{~m}^{3}\end{array}$ & 506 & 20 & 0.8 & 1 & 1 & 4 & 0 \\
\hline $\begin{array}{c}\text { Deposit 101- } \\
3 / 6\end{array}$ & $13.6 \mathrm{~m}^{3}$ & 50122 & 9 & 3.7 & n.d. & n.d. & n.d. & 35 \\
\hline
\end{tabular}

\footnotetext{
* Excavated volume

† MSW - mean sherd weight
} 
soil samples include the reliability of measurements for different elements and the comparability with results obtained by other techniques. In a study by R. K. Gauss et al. (2013), the relative standard deviation has been found to lie below ten percent for all elements except manganese. Concerning comparability, the results of phosphorus measurements by $\mathrm{XRF}$ and by pressure-temperature extraction with aqua regia reveal a consistently high correlation of r2 $=0.97$ (coefficient of determination), but the values determined by XRF are $70 \%$ higher on average. Both technical overestimation on the part of the pXRF analyser and methodological issues, such as incomplete chemical extraction, may account for this significant difference (Nowaczinski et al. 2013).

\section{RESULTS}

\section{Pit 101-29}

Pit 101-29 was filled with a uniform-looking dark grayish-brown sediment (Deposit 101-27) containing frequent small to medium-sized pottery sherds, pieces of charcoal and occasional daub fragments. The highest concentrations of pottery, animal bones and daub (both in absolute weight and in terms of density) were found in the upper third of this pit (Table 1). The MSW ranged between 9 and $11 \mathrm{~g}$ without a marked vertical trend. Small finds appeared in all three thirds, with a notable gap between 45 and $90 \mathrm{~cm}$ of depth.

Pit 101-29 provided a wide range of botanical and zoological remains. Charred Chenopodiaceae seeds occur in all samples. A notable concentration of phosphatized Chenopodiaceae seeds was found at the base of the upper third. Fragments of cereals are most common in the uppermost sample as well as in the lower three ones, with very small fragments $(<0.71 \mathrm{~mm})$ dominating at the base. The total charcoal concentrations remain below $4 \mathrm{~g} / \mathrm{l}$. The charcoal spectra are dominated by Quercus (73\%). Fraxinus (19\%) occurs in the uppermost and the three basal samples reaching portions of 35 to $55 \%$. The concentration of snail shells is uniformly low throughout (3.5-7.5 n/l). Vallonia pulchella and Truncatellina cylindrical are the most common species. While Pupilla muscorum and Clausiliidae appear in most of the spectra, Cochlicopa lubrica is restricted to three successive samples near the base. For the Clausiliidae only small fragments and young apices were found allowing no species determination. The mammal bones were fragmented and showed characteristic traces of butchering, and thus probably originated from domestic rubbish containing food remains. Bones of domestic animals, mainly cattle, predominated (Table 2).

The content of phosphorus in Pit 101-29 shows a clear pattern of vertical distribution (Fig. 6; Table 3). The soil above the neck has an elevated content of phosphorus $(\mathrm{P})$. The sharp decline in $\mathrm{P}$ in the deposit of the pit neck is particularly remarkable, while the fill in the body of the pit shows uniformly lower values. This stratification in the chemical composition of the deposits does not correlate well with the distribution of archaeological finds. It seems that the two classes of data, finds density and soil chemistry, relate to different aspects of fill formation.

Table 2. Vráble. Pit 29 and 42. Species composition of the faunal remains.

\begin{tabular}{|l|c|c|c|c|}
\cline { 2 - 4 } \multicolumn{1}{c|}{} & \multicolumn{2}{c|}{ Pit 29 } & Number & Weight g \\
\cline { 2 - 5 } \multicolumn{1}{c|}{} & Number & Weight g & 10 & 329 \\
\hline Cattle & 32 & 834 & 12 & 127 \\
Pig & 28 & 167 & 9 & 31 \\
Sheep/goat & 18 & 101 & - & - \\
Dog & 8 & 68 & - & - \\
Cattle/Auerochs & 1 & 47 & - & 71 \\
Domestic/wild pig & 1 & 14 & 2 & 100 \\
Red deer & 6 & 206 & 1 & - \\
Red deer, antler & - & - & - & 44 \\
Roe deer & 1 & 12 & - & - \\
Wild boar & 2 & 55 & - & - \\
Badger & 1 & 12 & 51 & 155 \\
Hare & 1 & 4 & 30 & 973 \\
River mussels & 174 & 348 & 116 & - \\
Undeterminate (mammals) & 142 & 344 & -216 \\
\hline Total & 415 & 2,212 & - & \\
\hline
\end{tabular}




\section{Pit 101-42}

Pit 101-42 displayed a more complex sedimentation history. On the bottom of the pit was a ca. $15 \mathrm{~cm}$ thick layer of compact brown sediment (Deposit 101-154). The cone-shaped appearance suggests that this deposit was formed when soil seeped into the empty pit through its narrow opening. This most likely natural infill was superimposed by a stratum of ca. $15 \mathrm{~cm}$, consisting of several thin layers of yellow loess and a stratum of red and brown fired daub with pieces of charcoal (Deposit 101-149). The main part of the fill (Deposit 101-72) consisted of soft, loose, light brown silty sediment with a thickness
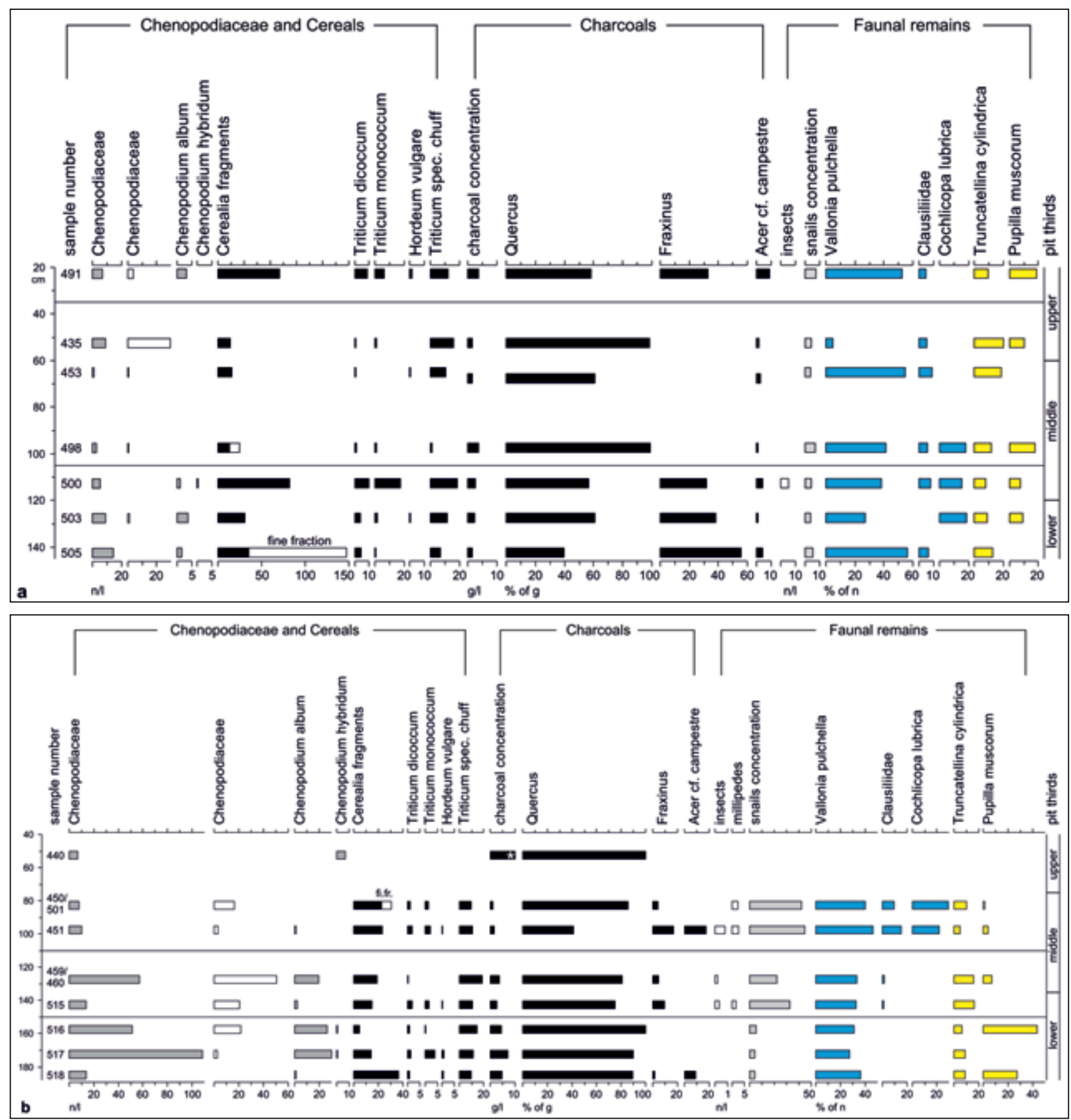

Fig. 5. Vráble. a - Pit 101-29, selected macro remains from flotation samples drawn against the middle sample depth below pit surface. Botanical and arthropod remains expressed as concentration (n/l), mineralized (phosphatized amounts of the sum of Chenopodiaceae given as percentages of all charred (ch) and mineralized (min) Chenopodiaceae seeds (\% min), extent of fine fraction $(<0.71 \mathrm{~mm})$ of cereal fragments indicated white. Values of wood taxa in percentages of the charcoal weight (\% of g). Percentages of snails refer to the minimum number of individuals (\% of $n$ ) with species of wet places in blue and of dry places in yellow. Horizontal lines indicate marked changes in spectra composition; $b-$ like a but for Pit 101-42 (fi. fr, fine fraction). ${ }^{*}$ Charcoal concentration in vessel sample 440 was $138 \mathrm{~g} / 1$ (author F. Schlütz). 


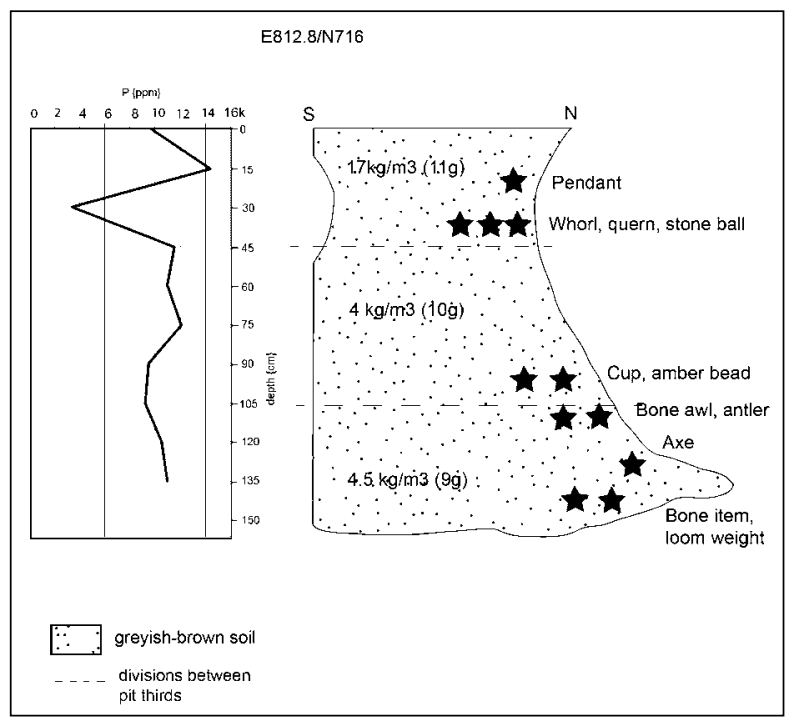

Fig. 6. Sherd density, distribution of small finds and soil chemistry. Numbers in brackets indicate the Mean Sherd Weights/MSW (author M. Ivanova).

of ca. $1.2 \mathrm{~m}$. It contained a considerable amount of small fired daub fragments and numerous sherds and bones and exhibited in its upper part signs of slumping. Deposit 101-72 apparently settled over time, creating a central hollow that was filled with loose, dark greyish-brown soil (Deposit 101-41). Finally, the entire area was covered with a thick layer of loose ashy soil containing rubbish, (Deposits 101-24 and 101-6), possibly from an old midden (Fig. 3).

The vertical distribution of finds in Pit 101-42 is remarkable. In contrast to Pit 101-29, the upper third contained little archaeological material. A significant concentration of archaeological finds was observed in the middle third (Table 1), but most finds occurred in the lowest part of Deposit 101-72 at a depth of 1.2-1.5 m, overlying the conspicuous Deposit 101-149. The finds assemblage from the lowest part of the pit (Deposit 101-154) was also unusual. While the MSW in the other levels of the pit was quite uniform and with 10-12 g similar to that of Pit 101-29, the sherds of Deposit 101-154 had an unusually high MSW of $20 \mathrm{~g}$. Pit 101-42 did not contain any notable small archaeological finds beside the two nearly complete ceramic jugs in the upper and the middle third already mentioned.

The plant and faunal remains show clear vertical trends (Fig. 5). The number of charred seeds of Chenopodiaceae reaches their highest value with over $100 \mathrm{n} / \mathrm{l}$ in the lower pit third. The most common determined Chenopodiaceae species is Chenopodium album. Remains of cereals, represented by charred grains, grain fragments and chaff, are more evenly distributed. Emmer (Triticum dicoccum) and einkorn (T. monococcum), two hulled wheat species, are dominating, while barley (Hordeum vulgare) is sporadic. Charcoals appear with around $5 \mathrm{~g} / \mathrm{l}$ or less. The charcoal spectra are strongly dominated by Quercus (84 \%), followed by Fraxinus (3\%) and Acer cf. campestre (2\%). In the lowermost three samples, Quercus reaches nearly 90-100\%, while remains of arthropods (insects, millipedes) are missing. The single sample from the upper third (sample 440) is from inside a vessel. This sample appears aberrant by the presence of Chenopodium hybridum, a species otherwise nearly absent, and an extreme high charcoal concentration of $138 \mathrm{~g} / \mathrm{l}$.

Pit 101-42 was rich in snail remains, revealing not less than 15 snail taxa. The concentration of shells was up to $50 \mathrm{n} / \mathrm{l}$ with shells of Vallonia pulchella and Truncatellina cylindrica appearing in every sample. The three basal samples differ by less than $5 \mathrm{n} / \mathrm{l}$ and high proportions of Pupilla muscorum of up to $44 \%$. The samples from the upper middle third are characterized by relative high values of Clausiliidae (10-15\%) and the occurrence of Cochlicopa lubrica (22-29\%). The vessel filling (sample 440) was free of any snails finds. The composition of the mammal species in the faunal assemblage is similar to that of Pit 29 but the overall spectrum is narrower and the number of wild mammals is lower (Table 2). The bones are fractured into small fragments and apparently originate from household garbage.

The chemical analysis of Pit 101-42 demonstrates a pattern of vertical distribution of phosphorus that is very similar to that in Pit 101-29 (Table 1; Fig. 7). While the deposit at the top had elevated contents of phosphorus, the values fell abruptly in the pit neck. The values of the pit body are higher than in the neck. Below $105 \mathrm{~cm}$ the values increase and reach in the lower pit third the same range as in the top samples. A notable peak in $\mathrm{P}$ at a depth of 1.65-1.90 m corresponds to Deposit 101-149.

\section{DISCUSSION}

\section{Stratigraphy and sedimentation}

Anthropogenic sediments are deposited by gravity and are therefore thicker and less homogenous than sediments deposited by natural events involving the action of water and wind, producing thin 'laminated' layers (Boschian/Colombo 2009). In Shackley's experiments at Danebury (South England), bell-shaped pits were left open for three years to observe natural sedimentation. The filling of these pits followed a particular pattern: the primary deposits included a 'dome' of soil, which tumbled in through the narrow opening of the pit, 


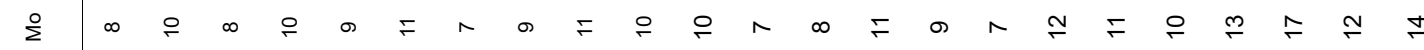

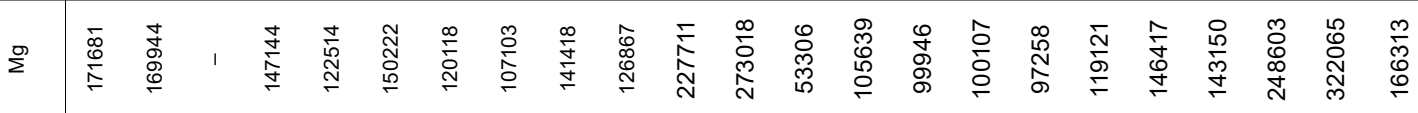

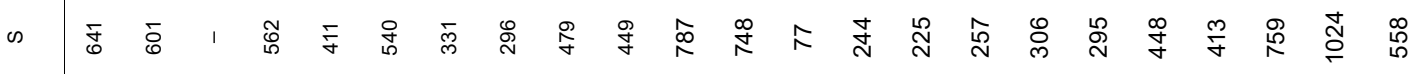

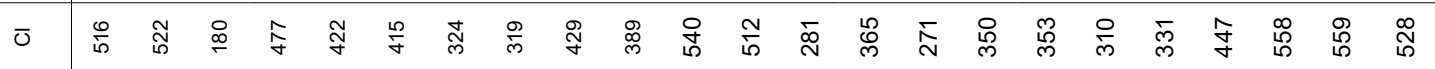

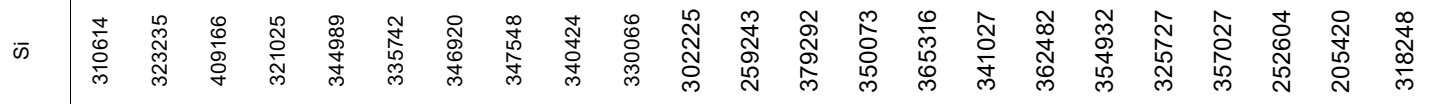

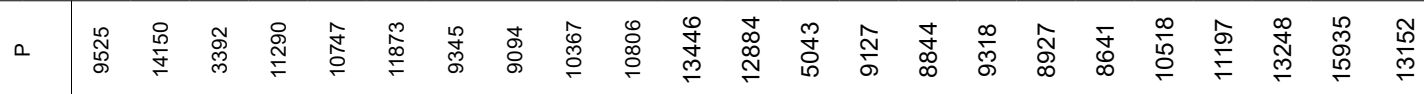

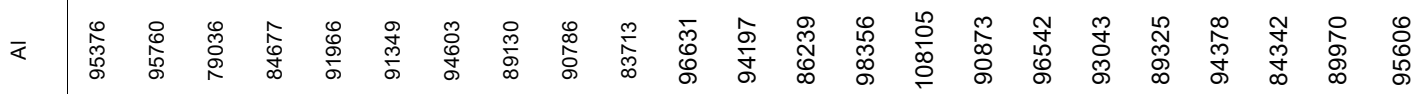

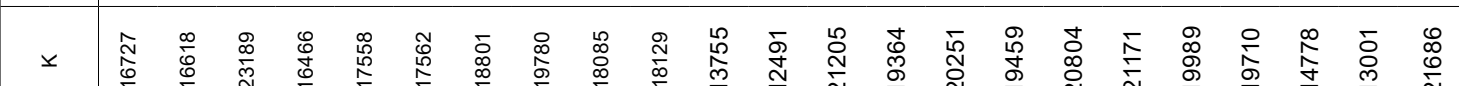

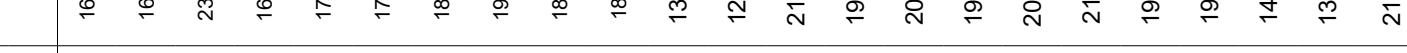

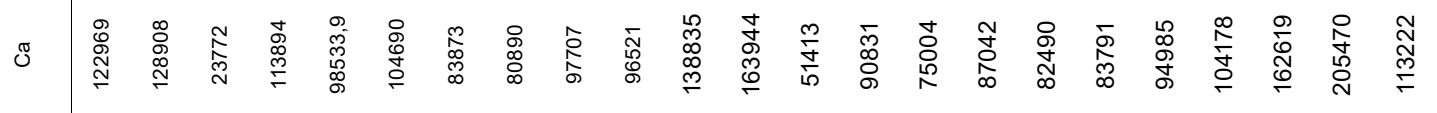

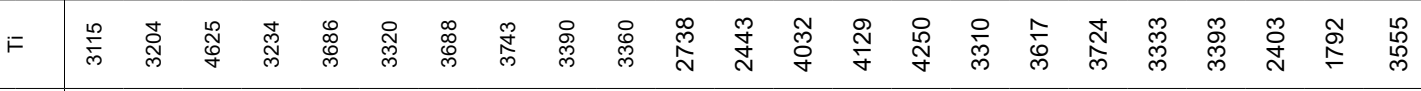
○

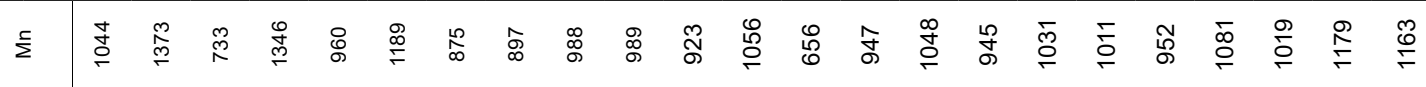

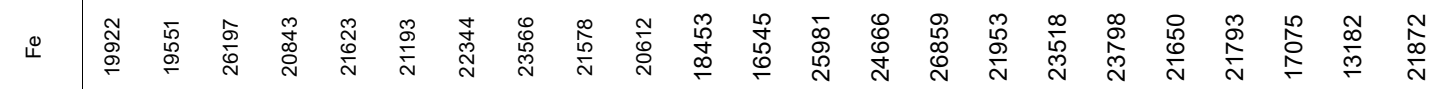
उ $\quad \mathcal{4}$ ஸ N

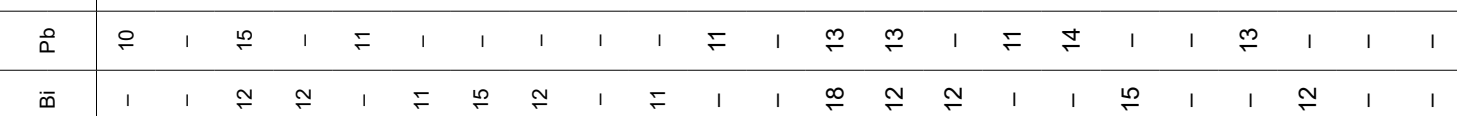
๙

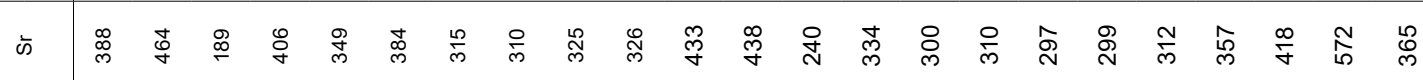

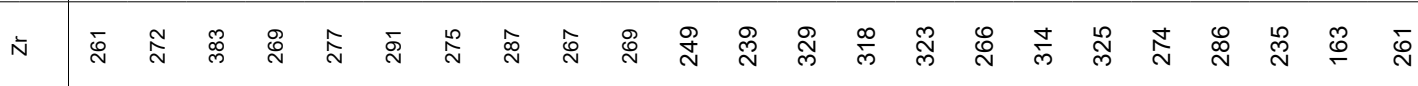

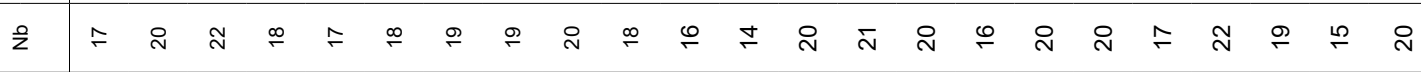
๓⿴囗⿰丿㇄心

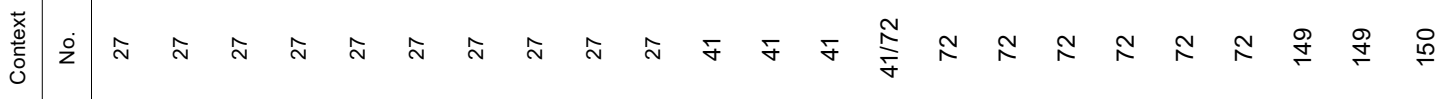
产 छ ஜ

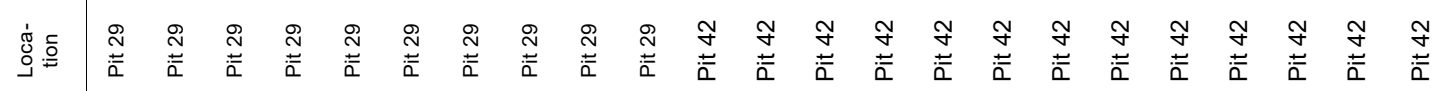

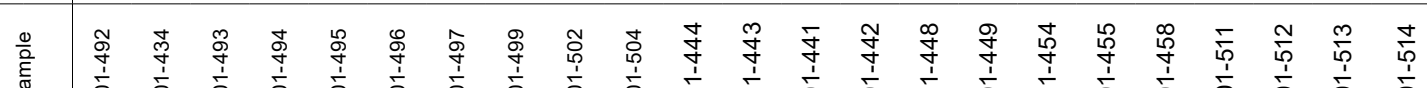
元 $\frac{0}{0}$ क 


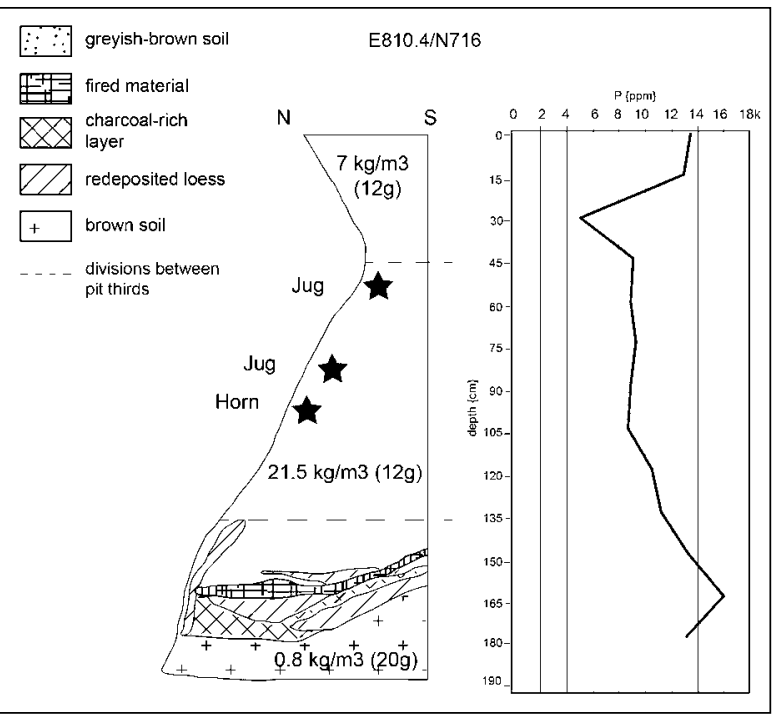

Fig. 7. Vráble, Pit 101-42. Sherd density, distribution of small finds and soil chemistry. Numbers in brackets indicate the Mean Sherd Weights/MSW (author M. Ivanova).

followed by fine-grained thin units produced by weathering of the walls. Later deposits comprised seasonal sequences of thick winter erosion layers from the walls and summer lenses of rain-washed soil. Overhanging walls usually started to collapse already during the first winter (Fig. 8; Shackley 1976; see also Gronenborn 1997, 436 with similar observations; Pavúk 1994, 83).

At Vráble, Pit 101-42 shows characteristics of both anthropogenic and natural infilling. On its bottom a characteristic 'dome' was uncovered, likely representing material which was thrown in and/or seeped in through the narrow opening of the pit (Deposit 101-154). The superimposed unit (Deposit 101-149), consisting of laminated layers with material eroded from the overhanging walls and thin layers of soil washed in by wind and water, speaks for a period in which there was a stagnation in human activity. This suggests that Pit 101-42 remained open for some time. The youngest part of the fill is a mixture of habitation debris, most likely filled in by humans in one event. In contrast, traces of natural deposition, such as silting and rain wash, were absent in Pit 101-29. Since evidence for periods of stasis was not observed, the entire Pit 101-29 must have been filled with soil dumped intentionally in a single event. The anthropogenic fill material in both pits most probably derived from the occupation debris in the nearest vicinity of the pits. They are very similar to Deposit 101-3/6, the greyish layer that overlies the sealed pits. This loose ashy deposit contained frequent middle-sized pieces of daub, pottery sherds, occasional bones and stones, mixed with small pieces of charcoal and clamshells (Table 1).

When digging the two pits for grain storage, people handled a total of up to $5 \mathrm{~m}^{3}$ of loess. Apparently, this excess loess was not stored for the later refilling. Possibly the loess was spread around and became intermingled or was utilized for house constructions or other purposes.

Neither of the pits was damaged by heavy erosion or a total collapse of the overhanging profiles. To explain the well-preserved pit profiles at Micheldever Wood, P. J. Fasham $(1987,78)$ suggested that pits were intentionally filled in when not used for grain storage. This practice is attested in modern farming, too. The Department of Agriculture and the State of Western Australia, for example, recommends to fill

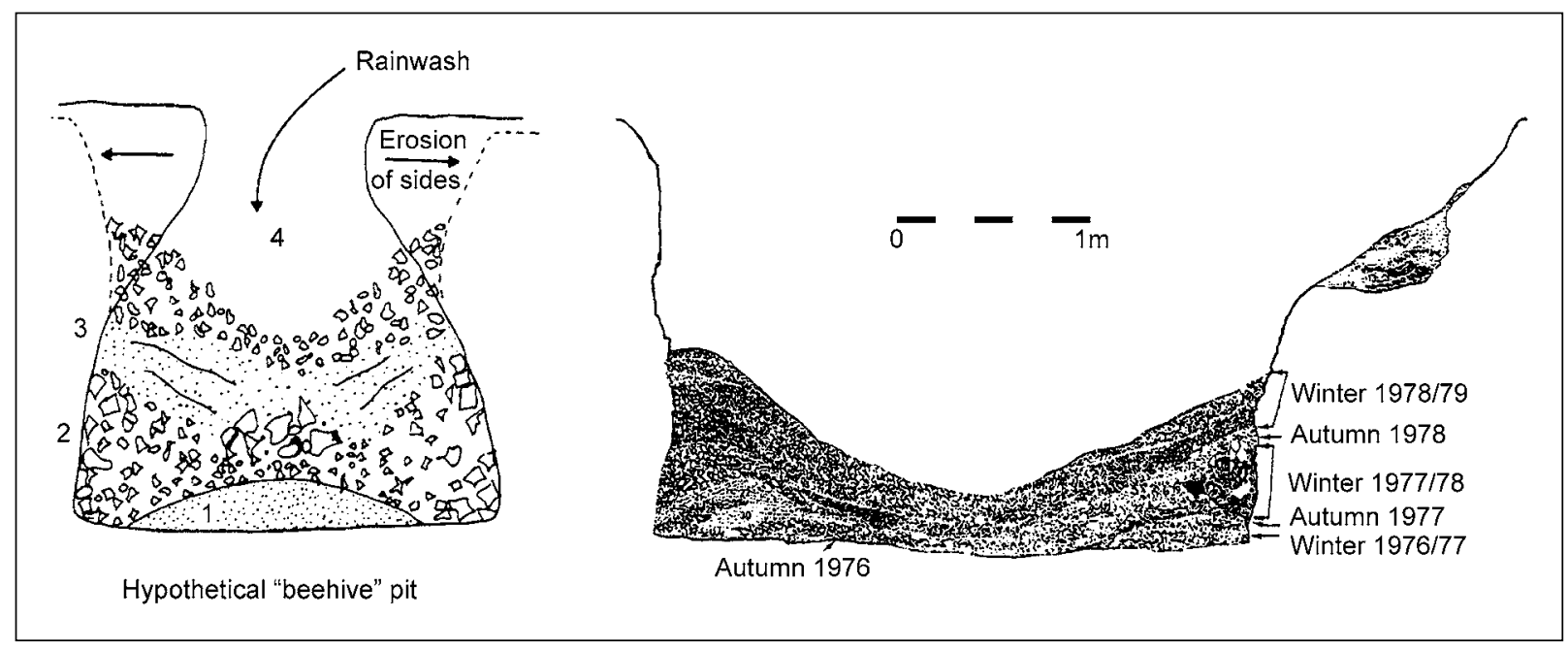

Fig. 8. Natural sedimentation in bell-shaped pits (after Hill 1995, fig. 3: 4b; Shackley 1976, fig. 5). 
empty storage pits with soil in order to protect them from dampness and rain, reopening them only when the need arises (Newman 2003). The stratigraphy of the two storage pits at Vráble suggests that a similar practice was applied in prehistoric times. Further aspects of pit filling are elucidated by the finds assemblages and the soil chemistry of the deposits.

\section{Finds assemblages}

Finds, such as artifacts, animal bones, clamshells, snails, charred plant remains and fired daub are either intentionally deposited into a pit or enter with the sediments that were artificially dumped or naturally eroded. In the latter case, finds may have become incorporated in the soil deliberately, when discarded by dumping, or accidentally, when scattered on yard floors or alleys. Ethnoarchaeological research suggests that the state of the finds may help to establish their origin (Beck 2006 with further references; Deal 1985; Nielsen 1991). Larger and wellpreserved objects, for example, are usually absent in contexts which were exposed to weathering, trampling and scattering, such as in old middens and areas of traffic.

At Vráble, the density and degree of fragmentation of the finds varied throughout the backfills. In Pit 101-29, there was a remarkable concentration of artifacts in the upper third (Fig. 6). In his study on Iron Age pits J. D. Hill (1995, 45, 52, 53) observed comparable pattern in the vertical distribution of finds. He proposed that the hollows created by settling of the pits' fill acted as traps for smaller objects from the 'background soil' in the surroundings. Large objects, such as loom weights, querns and big sherds, in contrast, are generally discovered in the lower and middle thirds, probably because fresh 'curated' material was rarely present in the background soil and thus unlikely to become deposited in the uppermost fill. The assemblage of large sherds in the bottom deposit of Pit 101-41 with a MSW of $20 \mathrm{~g}$ may represent such intentionally deposited 'curated rubbish'.

\section{Microscopical hints on the environmental background and the filling of the pits}

The snail taxa of the infillings point to a generally open environment around the pits. Especially the common species Vallonia pulchella and Truncatellina cylindrica prefer shady ( $V$. pulchella) respectively sunny (T. cylindrica) places with a sparse cover of low grasses or herbs, while Pupilla muscorum point to sunny sites with a somewhat higher and denser cover.
Clausiliidae and Cochlicopa lubrica are more specialized and discerning in their ecological requirements. The Clausiliidae are a group of snails browsing small algae and lichens on natural vertical structures like rocks and tree bark. Cochlicopa lubrica needs places with wet organic material like grasses, mosses, leaves or wood remains.

The first low finds of Clausiliidae in Pit 100-42 are accompanied by phosphatized remains of insects and millipedes and higher values of Clausiliidae go together in addition with finds of Cochlicopa lubrica. This combination may point to material taken from the near house ruins north of the pit. Organic material accumulating along the wall fragments and in their corners and winkles could give good habitats to Cochlicopa lubrica, insects and millipedes. Such moist and shady places are also comfortable shelters for Clausiliidae browsing on the wall fragments. These sediments from the ruined walls were probably also somewhat richer in charcoals of Fraxinus and Acer cf. campestre. The base of pit 100-29 yielded a high amount of small cereal fragments. These pieces may originate from grains crashed by trampling and other activities during the use of the pit and thrown into the pit with the first refilling loads. These cultural residues from probably near the pit opening are quite rich in Fraxinus charcoal and may have therefore partly originated from the nearby ruins (Cochlicopa lubrica). The refill of the next $70 \mathrm{~cm}$ of the pit is free of Fraxinus charcoals and low in cereal fragments, obviously taken by the people from another location. In the end again material rich in Cereal fragments and Fraxinus charcoal was thrown into the pit.

The original source of the charred cereals remains might be partly the cereal storages of the brunt house, in which the later pits were dug. The same might be true for the charcoals found. The charred Chenopodiaceae seeds, especially where their number exceed many times over the cereals, could point to burnt waste from the grain cleaning. But it is also likely that Goosefoot plants grew on the nutrient-rich cultural soils of the ruins. Seeds of such plants were probably eaten by animals and became mineralized by the phosphorus of the dung after defecation and were later relocated into the pits, thus explaining the presence of mineralized Chenopodiaceae seeds in the fills. This could suggest that domestic animals grazed in the pit area as described by P. J. Reynolds (1974) and K. R. Robinson (1963) for ethnographic contexts:

'A Matebele kraalhead, Johni Inkome, of Sibomvu Township, Essexvale, gave me these details with regard to the Ndebele type grain storage pit. (a) The pit was dug in the cattle-kraal. (b) In form the pit was more or less gourd-shaped, but very much 
larger than any of the pits described above as a man could get into one quite easily and stand upright. \{...\} (e) Mabela was put inside and the opening closed with stone slabs sealed with termite mound. (f) Cattle dung was also placed over the stones, and allowed to accumulate. (g) The reason for siting the pits in a cattle-kraal was alleged to be that the heat of the manure assisted in the curing of the grain, and the tramping of the cattle prevented damp from entering.' (Robinson 1963, 63).

We cannot exclude that dung was also collected as fuel and the phosphatized and burnt Chenopodiaceae seeds were deposited with the ash at the pit site.

\section{Soil chemistry}

Human action not only modifies the structure of the soil matrix but also affects its chemical composition. Some chemical elements form stable and immobile compounds and can therefore potentially serve as reliable indicators for human occupation in the distant past. Ethnoarchaeological research suggests that elements such as phosphorus, calcium, potassium and manganese relate to particular human activities at settlement sites (Middleton 2004; Middleton/Price 1996). Among them, phosphorus is probably the most widely used anthropogenic indicator in archaeology. Phosphorus enters the soil in residential areas through the deposition of organic refuse (especially food residues, ash and animal dung) and becomes rapidly 'fixed' in form of stable compounds (Bethell/Máté 1989).

Furthermore, ethnoarchaeological research and experimental data demonstrate a relationship between P levels and domestic activities. Cooking areas and middens generally exhibit elevated levels of phosphorus. Surfaces subjected to cleaning and traffic, such as house floors, craft production areas and pathways, by contrast, show low levels of $\mathrm{P}$ (Holliday/Gartner 2007). Ethnoarchaeological observations further suggest that the P enrichment of midden deposits remains surprisingly stable; even if the midden was physically removed, elevated $P$ levels continue to exist in the underlying soil (Beck 2007; comprehensive discussion also in Gauss et al. 2013).

Vertical variation in the P content of Pit 101-29 and Pit 101-42 includes a sequence of comparatively high levels of phosphorus above the neck, a notable fall of the $P$ content in the neck and uniform values around 10,000 ppm in the pit body (Fig. 6; 7). This pattern suggests that the deposits in the upper and those in the middle/lower parts differed in their formation. A likely explanation for the uniform values in the pit body is the rapid and intentional filling-in of the pits with mixed soil from an old midden. The elevated levels of phosphorus above the pit necks suggest that these deposits developed more slowly by gradual sedimentation in a depression that formed after the initial backfill had settled. Similar P enrichments in the uppermost part of fills were observed in the study of Late Bronze Age pits at Prague 10-Záběhlice (Ernée 2005). Finally, we see a correlation between higher $\mathrm{P}$ contents in the lower part of Pit 101-42 (Fig. 7) and the presence of fired materials, supporting the observation that phosphorus is enriched in ashes (cf. Gauss et al. 2013, 2951). Here, the correspondence of elevated contents of $\mathrm{P}$, burned material and Chenopodiaceae probably indicates the presence of animal dung and its possible use as a fuel.

\section{CONCLUSIONS AND PERSPECTIVES}

Both examined pits were filled with material that probably derived from old midden deposits, containing numerous small and eroded pottery sherds, animal bones, charcoal and other waste. The evidence strongly suggests that the two pits in this case study were not used for regular disposal of waste. In the latter case, much more variation in the composition of sediments, condition and concentration of finds and of soil chemistry within the fills would be expected. It appears that the pits were deliberately filled with the intent to protect the vulnerable overhanging necks from collapse and thus to conserve the facilities for future re-use and to prevent accidents of humans or domestic animals.

The correlations between the bioarchaeological and geochemical proxies provide interesting information about the origin of the pit fills. Phosphorus appears to give clues to the formation of deposits that otherwise cannot be subdivided stratigraphically. The combination of geochemical (soil chemistry) and bioarchaeological (microscopic plant remains and snails) indicators helps to differentiate distinct parts of the fill even in deposits that appear uniform, while the association of elevated $P$ values with mineralized Chenopodiaceae suggests the presence of animal dung. The compositions of the botanical assemblages show that the deposits in the two pits originated from different areas, and thus demonstrate the potential of the analyses of microremains for comparing between features. From all proxies, artifact density appears most problematic, since it correlates neither with distribution of $\mathrm{P}$ nor with other finds. More data is needed to clarify this counterintuitive finding. In conclusion, the combination of data from different sources clearly helps to establish more firm correla- 
tions between deposits and activities and to make suppositions about human activities in the vicinity of subterranean features. For regions and periods where pits are the major or only archaeological feature at prehistoric sites, such detailed analyses can provide valuable insights into the economic, social and ritual practices of former societies.

\section{Acknowledgements}

This work has been carried out as part of the international collaborative project 'Vráble, an Early Bronze Age Center in Southwest Slovakia', funded by the German Research Foundation (DFG, RA
557/5, BI 783/5). We thank the project directors J. Bátora (University of Bratislava), K. Rassmann (RGK Frankfurt, German Archaeological Institute) and F. Bittmann (NIhK, Wilhelmshaven) for their support. The preparation of the soil samples and the pXRF measurements were conducted at the Laboratory for Geomorphology and Geoecology at the University of Heidelberg's Institute of Geography. We are grateful to E. Nowaczinski and G. Schukraft for providing the data and helpful discussions. M. Przybyła (Instytut Archeologii UJ, Kraków) offered thoughts on an earlier version of this paper and drew our attention to relevant publications.

\section{LITERATURE}

Balbo et al. 2015 - A. L. Balbo/D. Cabanes/J. J. García-Granero/A. Bonet/P. Ajithprasad/X. Terradas: A microarchaeological approach for the study of pits. Environmental Archaeology 20, 2015, 390-405.

Bátora et al. 2009 - J. Bátora/B. Eitel/S. Hecht/A. Koch/ K. Rassmann/G. Schukraft/K. Winkelmann: Fidvár bei Vráble (Kr. Nitra, Südwestslowakei). Untersuchungen auf einem äneolithisch-frühbronzezeitlichen Siedlungshügel. Germania 87, 2009, 1-23.

Bátora et al. 2012 - J. Bátora/A. Behrens/J. Gresky/M. Ivanova/K. Rassmann/P. Tóth/K. Winkelmann: The rise and decline of the Early Bronze Age settlement Fidvár near Vráble, Slovakia. In: J. Kneisel/W. Kirleis/M. Dal Corso/N. Taylor/V. Tiedtke (eds.): Collapse or Continuity? Environment and Development of Bronze Age Human Landscapes. Proceedings of the International Workshop "Socio-Environmental Dynamics over the Last 12,000 Years: The Creation of Landscapes II (14th-18th of March 2011) in Kiel. Bonn 2012, 111-129.

Beck 2006 - M. E. Beck: Midden ceramic assemblage formation. A case study from Kalinga, Philippines. American Antiquity 71, 2006, 27-51.

Beck 2007 - M. E. Beck: Midden formation and intrasite chemical patterning in Kalinga, Philippines. Geoarchaeology 22, 2007, 453-475.

Berggren 1981 - G. Berggren: Atlas of seeds and small fruits of Northwest-European plant species (Sweden, Norway, Denmark, East Fennoscandia and Iceland) with morphological descriptions. Part 3: Salicaceae-Cruciferae. Stockholm 1981.

Bethell/Máté 1989 - P. Bethell/I. Máté: The use of soil phosphate analysis in archaeology. A critique. In: J. Henderson (ed.): Scientific Analysis in Archaeology and Its Interpretation. Archaeological Research Tools 5. Los Angeles 1989, 1-29.

Bojňanský/Fargašová 2007 - V. Bojňanský/A. Fargašová: Atlas of seeds and fruits of Central and East-European flora. The Carpathian Mountains Region. Dordrecht 2007.

Boschian/Colombo 2009 - G. Boschian/M. Colombo: Infilling processes of large pit features at Catignano - Neolithic (Italy). In: F. Cavulli (ed.): Defining a Methodological Approach to Interpret Structural Evidence. Proceedings of the XV World Congress of the International Union for Prehistoric and Protohistoric Sciences. BAR 2045. Oxford 2009, 43-50.
Carrott/Kenward/Milles 1996 - J. Carrott/H. Kenward/ A. Milles: Mollusc remains from excavations at an Iron Age and Romano-British settlement site at Melton, North Humberside (site code: MEL94). Technical report. Reports from the Environmental Archaeology Unit, York 96/24. York 1996. Currid/Navon 1989 - J. D. Currid/A. Navon: Iron Age Pits and the Lahav (Tell Halif) Grain Storage Project. Bulletin of the American Schools of Oriental Research 273, 1989, 67-78.

Davies 2008 - P. Davies: Snails - Archaeology and landscape change. Oxford 2008.

Deal 1985 -M. Deal: Household pottery disposal in the Maya Highlands. An ethnoarchaeological interpretation. Journal of Anthropological Archaeology 4, 1985, 243-291.

Ernée 2005 - M. Ernée: Využití fosfátové půdní analýzy při interpretaci kulturního souvrství a zahloubených objektů z mladší a pozdní doby bronzové v Praze 10 - Záběhlicích. Archeologické rozhledy 57, 2005, 303-333.

Ernée 2008 - M. Ernée: Pravěké kulturní souvrství jako archeologický pramen. Památky archeologické. Supplementum 20. Praha 2008.

Evans 1972 - J. G. Evans: Land snails in archaeology with special reference to the British Isles. Studies in archaeology science. London 1972.

Fairbairn/Omura 2005 - A. Fairbairn/S. Omura: Archaeological identification and significance of ÉSAG (Agricultural Storage Pits) at Kaman - Kalehöyük, Central Anatolia. Anatolian Studies 55, 2005, 15-23.

Fasham 1987 - P. J. Fasham: A 'banjo' enclosure in Micheldever Wood, Hampshire. Hampshire 1987.

Fenton 1983 - A. Fenton: Grain storage in pits. Experiment and fact. In: A. O'Connor/D. V. Clarke (eds.): From the Stone Age to the ,Forty-Five'. Studies presented to R. B. K. Stevenson. Edinburgh 1983, 567-588.

Frahm 2013 - E. Frahm: Is obsidian sourcing about geochemistry or archaeology? A reply to Speakman and Shackley. Journal of Archaeological Science 40, 2013, 1444-1448.

Frahm/Doonan 2013 - E. Frahm/R. C. P. Doonan: The technological versus methodological revolution of portable XRF in archaeology. Journal of Archaeological Science 40, 2013, 1425-1434.

Füzes 1981 - E. Füzes: Die traditionelle Getreideaufbewahrung im Karpatenbecken. In: M. Gast/F. Sigaut (éds.): 
Les techniques de conservation des grains à long terme. Paris 1981, 66-83.

Gauss et al. 2013 - R. K. Gauss/J. Bátora/E. Nowaczinski/ K. Rassmann/G. Schukraft: The Early Bronze Age settlement of Fidvár, Vráble (Slovakia). Reconstructing prehistoric settlement patterns using portable XRF. Journal of Archaeological Science 40, 2013, 2942-2960.

Gogâltan 2008 - F. Gogâltan: Fortified Bronze Age tell settlements in the Carpathian Basin. A general overview. In: J. Czebreszuk/S. Kadrow/J. Müller (eds.): Defensive structures from Central Europe to the Aegean in the $3^{\text {rd }}$ and $2^{\text {nd }}$ millenia BC. Studien zur Archäologie in Ostmitteleuropa 5. Bonn 2008, 39-56.

Gronenborn 1997 -D. Gronenborn: An ancient storage pit in the SW Chad Basin, Nigeria. Journal of Field Archaeology 24, 1997, 431-439.

Gundlach 1961-H. Gundlach: Tüpfelmethode auf Phosphat, angewandt in prähistorischer Forschung (als Feldmethode). Microchimica Acta 49, 1961, 735-737.

Hill 1995 - J. D. Hill: Ritual and rubbish in the Iron Age of Wessex. A study on the formation of a specific archaeological record. BAR 242. Oxford 1995.

Holliday/Gartner 2007 - V. T. Holliday/W. G. Gartner: Methods of soil P analysis in archaeology. Journal of Archaeological Science 34, 2007, 301-333.

Jacomet 2006 - S. Jacomet: Bestimmung von Getreidefunden aus archäologischen Ausgrabungen. Basel 2006.

Juggins 2007 - S. Juggins: C2 Version 1.5 User guide. Software for ecological and palaeoecological data analysis and visualisation. Newcastle upon Tyne 2007.

Kadim 2014 - O. Kadim: A participatory approach to post-harvest loss assessment: underground and outdoor cereal storage in Doukkala, Morocco. In: A. L. van Gijn/J. C. Whittaker/P. C. Anderson (eds.): Explaining and exploring diversity in agricultural technology. Oxford 2014, 199-203.

Kadrow 1992 - S. Kadrow: Pottery fragmentation and dynamics of depositional processes inside trapeze-shaped features. Archaeologia Polona 30, 1992, 69-74.

Kerney et al. 1983 - M. P. Kerney/R. A. D. Cameron/ J. H. Jungbluth/G. Riley: Die Landschnecken Nord- und Mitteleuropas. Ein Bestimmungsbuch für Biologen und Naturfreunde. Hamburg 1983.

Kreuz/Schäfer 2002 - A. Kreuz/E. Schäfer: A new archaeobotanical database program. Vegetation History and Archaeobotany 11, 2002, 177-180.

Kuna/Němcová 2012 - M. Kuna/A. Němcová: Výpověd' sídlištního odpadu. Nálezy z pozdní doby bronzovév Roztokách u Prahy a otázka depozitní analýzy archeologického kontextu. Praha 2012.

Makal 1954 - M. Makal: A Village in Anatolia. London 1954.

Middleton 2004 - W. D. Middleton: Identifying chemical activity residues on prehistoric house floors. A methodology and rationale for multi-elemental characterization of a mild acid extract of anthropogenic sediments. Archaeometry 46, 2004, 47-65.
Middleton/Price 1996 - W. D. Middleton/T. D. Price: Identification of activity areas by multi-element characterization of sediments from modern and archaeological house floors using inductively coupled plasma-atomic emission spectroscopy. Journal of Archaeological Science 23, 1996, 673-687.

Mruškovič 1962 -Š. Mruškovič: Príspevok k uskladňovaniu obilia v obilných jamách na Záhorí. Musaica. Sborník Filozofickej fakulty Univerzity Komenského 13, 1962, 59, 60.

Newman 2003 - C. Newman: Stored grain management. Underground storage of grain. Farmnote 70, 2003.

Nicolaisen 1963 - J. Nicolaisen: Ecology and Culture of the Pastoral Tuareq. Copenhagen 1963.

Nielsen 1991 - A. E. Nielsen: Trampling the archaeological record. American Antiquity 56, 1991, 483-503.

Nowaczinski et al. 2013 - E. Nowaczinski/G. Schukraft/ K. Rassmann/S. Hecht/F. Texier/B. Eitel/O. Bubenzer: Geophysical-geochemical reconstruction of an ancient population size - the Early Bronze Age settlement of Fidvár (Slovakia). Archaeological Prospection 20, 2013, 267-283.

Pavúk 1994 - J. Pavúk: Štúrovo. Ein Siedlungsplatz der Kultur mit Linearkeramik und der Želiezovce-Gruppe. Nitra 1994.

Peters 1979 - E. Peters: Vorratshaltung in der anonymen Architektur der Altinova. In: S. Pekman (ed.): Keban Project 1973 Activities. Ankara 1979, 125-142.

Reynolds 1974 - P. J. Reynolds: Experimental Iron Age storage pits: an interim report. Proceedings of the Prehistoric Society 40, 1974, 118-131.

Robinson 1963 - K. R. Robinson: A Note on Storage Pits. Rhodesian Iron Age and Modern African. The South African Archaeological Bulletin 18, 1963, 62-63.

Shackley 1976 - M. L. Shackley: The Danebury Project. An experiment in site sediment recording. In: D. A. Davidson/M. L. Shackley (eds.): Geoarchaeology. Earth Science and the Past. London 1976, 9-21.

Speakman/Shackley 2013 - R. J. Speakman/M. S. Shackley: Silo science and portable XRF in archaeology. A response to Frahm. Journal of Archaeological Science 40, 2013, 1435-1443.

Točík 1982 - A. Točík: Beitrag zur Problematik befestigter Siedlungen in der Sudwestslowakei während der älteren und zu Beginn der mittleren Bronzezeit. In: B. Chropovský/J. Herrmann (Hrsg.): Beiträge zum bronzezeitlichen Burgenbau in Mitteleuropa. Berlin - Nitra 1982, 405-416.

Toffolo et al. 2018 - M. B. Toffolo/M. A. S. Martinc/D. M. Masterd/E. Boaretto: Microarchaeology of a grain silo. Insights into stratigraphy, chronology and food storage at Late Bronze Age Ashkelon, Israel. Journal of Archaeological Science. Reports 19, 2018, 177-188.

Welter-Schultes 2012 - F. W. Welter-Schultes: European non-marine molluscs, a guide for species identification. Bestimmungsbuch für europäische Land-und Süsswassermollusken. Göttingen 2012. 
Ass.-Prof. Dr. Maria Ivanova

Vienna Institute for Archaeological Science

University of Vienna

UZAII, Althanstrasse 14

A - 1090 Vienna

maria.ivanova@univie.ac.at

Dr. Frank Schlütz

Lower Saxony Institute for Historical Coastal Research

Viktoriastrasse 26/28

D - 26382 Wilhelmshaven

schluetz@nihk.de
Prof. Dr. Norbert Benecke

Deutsches Archäologisches Institut

Im Dol 2-6, Haus 2

D - 14195 Berlin

norbert.benecke@dainst.de

\title{
Podzemné silá vo Vrábloch, juhozápadné Slovensko \\ Prípadová štúdia zameraná na geochemickú analýzu a distribúciu nálezov vo výplni objektu
}

\author{
Maria Ivanova - Frank Schlütz - Norbert Benecke
}

\author{
SÚHRN
}

Predkladaná štúdia analyzuje potenciál detailného vzorkovania za účelom objasnenia pôvodu a tvorby sekundárnych výplní v podzemných zásobných objektoch. Analyzovaná bola stratigrafia, chemické zloženie pôdy a distribúcia predmetov, zvieracích kostí a mikroskopických zvyškov v zásype dvoch zásobných jám so zvoncovitým profilom zo staršej doby bronzovej (okolo 2000-1600 BC) z lokality Vráble-Fidvár na juhozápadnom Slovensku. Predkladané výsledky analýz demonštrujú, že integrácia viacerých proxy údajov dokáže poskytnút komplexnejší pohlad na tafonomickú históriu zahĺbených objektov a môže byt’ nápomocná pri rekonštrukcii špecifických ludských aktivít v ich susedstve. Pre oblasti, kde sú zahĺbené objekty hlavnými alebo jedinými archeologickými objektmi na pravekých lokalitách, môžu takéto detailné analýzy poskytnút hodnotné informácie o ekonomických, sociálnych a rituálnych praktikách pôvodných spoločností. 
